ISSN 0258-7122

Bangladesh J. Agril. Res. 40(2): 279-289, June 2015

\title{
EFFECTIVENESS OF DIFFERENT SUBSTRATE MATERIALS TO PREPARE Trichoderma harzianum BASED BIO-FUNGICIDES TO CONTROL FOOT AND ROOT ROT (Fusarium oxysporum) OF TOMATO
}

\author{
M. I. FARUK ${ }^{1}$, M. L. RAHMAN ${ }^{2}$, M. M. RAHMAN ${ }^{3}$ \\ R. ISLAM ${ }^{4}$ AND M. A. RAHMAN ${ }^{5}$
}

\begin{abstract}
An investigation was undertaken to evaluate the effectiveness Trichoderma harzianum based bio-fungicides multiplied on different substrates. The substrates was rice bran, wheat bran, grass pea bran and their combinations with mustard oilcake (MOC) were used to mass culture T. harzianum for the management of foot and root rot disease of tomato seedling caused by Fusarium oxysporum in seedbed. All combinations of carrier materials were found effective for preparing $T$. harzianum based bio-fungicides to promote germination, seedling growth and reducing pre-emergence and post-emergence mortality of tomato seedling under $F$. oxysporum inoculated seedbed soils. The shoot length, shoot weight, root length and root weight of tomato seedling were enhanced significantly by the application of different substrate materials of $T$. harzianum based bio-fungicides under $F$. oxysporum inoculated seedbed conditions. The individual (rice bran, wheat bran, grass pea bran) and combination of substrates (rice bran + wheat bran, rice bran + mustard oilcake, rice bran + wheat bran + MOC and wheat bran + grass pea bran + MOC) were equally suitable for mass culturing of effective $T$. harzianum bio-fungicides for the management of foot and root rot disease of tomato seedling in seedbed condition.
\end{abstract}

Keyword: Trichoderma harzianum, bio-fungicide, Fusarium oxysporum, tomato seedling, seedbed

\section{Introduction}

Tomato (Solanum lycopersicum L.) is one of the most popular vegetables in Bangladesh. The crop is cultivated in 24,800 hectare of land and the production is $232459 \mathrm{mt}$ of fruit annually (Anon., 2012). The crop suffers from many diseases and incurs 30-40\% yield loss every year (Anon., 1992). Among the diseases, seedling mortality due to the soil borne fungus, Fusarium oxysporum is prevalent throughout the tomato growing areas of the country (Anon., 19992). Management of $F$. oxysporum is difficult using fungicides and cultural practices.

\footnotetext{
${ }^{1 \& 3}$ Senior Scientific Officer, Plant Pathology Division, Bangladesh Agricultural Research Institute (BARI), ${ }^{2}$ Chief Scientific Officer, Training and Communication Wing, ${ }^{4}$ Scientific Officer, Plant Pathology Division, BARI, ${ }^{5}$ Chief Scientific Officer, Plant Pathology Division, BARI, Bangladesh.
} 
Therefore, an alternative method like biological control of disease management may be practice if available. Growth of pathogenic fungus can be reduced by means of antagonistic microorganisms, which kill or compete with the pathogenic fungus. The bio-control agent, T. harzianum is abundant in soil under all climates over different geographical regions. It is known as efficient decomposers of various substrates having rapid growth rates and antimicrobial properties. The bio- control agents are naturally present in soil usually in low population. Thus increasing of its population density through artificial inoculation is necessary to achieve successful control of target fungus in soil. Available reports reveal that rice bran, wheat bran, maize bran, sawdust (Das et al., 1997); rice straw, chickpea bran, grasspea bran, rice course powder, blackgram bran (Shamsuzzaman et al. 2003) and cow dung, poultry manure, groundnut shell, black ash (Rettinassababady and Ramadoss, 2000) are good substrates materials for multiplication of $T$ harzianum. Reports on the results of conclusive study on the use of substrates for multiplication of $T$ harzianum for the preparation bio-fungicides are not available in Bangladesh. The present investigation was conducted to evaluate effectiveness of different organic substrates for the preparation of $T$. harzianum based bio-fungicides against $F$. oxysporum causing foot and root rot disease of tomato in seedbed.

\section{Materials and Method}

Effectiveness of ten $T$. harzianum based bio-fungicides multiplied on three substrate materials was evaluated in the present experiment to control foot and root rot of tomato in seedbed. The substrate materials were rice bran, wheat bran, grasspea bran and their combinations mixed with or without mustard oilcake (MOC) were used to prepare the bio-fungicides. The experiment was conducted in a seedbed used under nethouse conditions of Plant Pathology Division, Bangladesh Agricultural Research Institute (BARl), Gazipur during three consecutive years from 2010 to 2014. In this experiment barley grains colonized with $F$. oxysporum were incorporated in the seedbed soils @ $100 \mathrm{~g} / \mathrm{m}^{2}$ soil. The pathogen was allowed to colonize the soil in seedbed for 10 days. A pure culture of T. harzianum (TM7) was grown in potato dextrose agar (PDA) medium which was used as inocula for preparation bio-fungicides.

The experiment was conducted in seedbed under nethouse condition of Plant Pathology Division, Bangladesh Agricultural Research Institute (BARI), Gazipur during three consecutive years from 2010 to 2014. In this experiment barley grains colonized with $F$. oxysporum were incorporated in the seedbed soils @ 100 $\mathrm{g} / \mathrm{m}^{2}$ soil for inoculation. The pathogen was allowed to multiply in seedbed soil for 10 days. A pure culture of T. harzianum (TM7) was grown in potato dextrose agar (PDA) medium which was used as inocula of bio-fungicide. The treatments in the experiment were $\mathrm{T}_{1}=$ Rice bran, $\mathrm{T}_{2}=$ Wheat bran, $\mathrm{T}_{3}=$ Grasspea bran, $\mathrm{T}_{4}=$ 
Rice bran + Wheat bran (1:1), $\mathrm{T}_{5}=$ Rice bran + Grasspea bran (1:1), $\mathrm{T}_{6}=$ Rice bran + Mustard oilcake (1:1), $\mathrm{T}_{7}=$ Rice bran + Wheat bran + MOC (1:1:1), $\mathrm{T}_{8}=$ Rice bran + Grasspea bran + MOC (1:1:1), $\mathrm{T}_{9}=$ Wheat bran + Grasspea bran + MOC $(1: 1: 1), T_{10}=$ Rice bran + Wheat bran + Grass pea bran $+\operatorname{MOC}(1: 1: 1: 1), T_{11}=$ Seed treatment with provax and $\mathrm{T}_{12}=$ Control. According to the treatment combinations $600 \mathrm{~g}$ of individual or combination of substrate materials were taken separately in $1000 \mathrm{ml}$ Erlenmeyer flask. The flask with substrate materials were sterilized in an autoclave at $121^{\circ} \mathrm{C}$ for 15 minutes and cooled down to make it ready for inoculation. The sterilized substrate was inoculated individually with $5 \mathrm{~mm}$ diameter mycelia disc of five-day old culture of $T$. harzianum grown on PDA and then incubated at room temperature $\left(25 \pm 2{ }^{\circ} \mathrm{C}\right)$ for 15 days. After incubation the colonized substrates were removed from the flasks and air dried and finally preserved in refrigerator at $10{ }^{\circ} \mathrm{C}$. The inoculum of T. harzianum, colonized on different substrates, were incorporated to the previously $F$. oxysporum inoculated seedbed soils @ $100 \mathrm{~g} / \mathrm{m}^{2}$ soil and kept for 7 days maintaining proper soil moisture to establish $T$. harzianum in the soils. The control bed did not receive any colonized substrate of $T$. harzianum except the inoculum of $F$. oxysporum. The seeds of BARI Tomato-2 (Raton) were sown in the seedbed @ 200 seeds per treatment. The initial germination of the seeds was 98\% as per blotter test result. The percent emergence of the seedling was calculated on the basis of initial germination status of the seeds. The experiment was laid out in completely randomized design (CRD) with four replications. Proper weeding, irrigation and intercultural operations were done to raise tomato seedlings in the seedbed. Data were collected on seedling emergence after 15 days of seed sowing. Similarly seedling mortality was recorded at an interval of 7 days starting from seedling emergence and it was continued up to 35 days of seedling age. The height and weight of shoot and length and weight of tomato seedlings were recorded at 35 days of seedling age. The percent data were converted into arcsine transformation values before statistical analysis. Data were analyzed statistically by using the MSTATC program. The treatment effects were compared by applying the least significant different (LSD) test at $\mathrm{P}=0.05$ level.

\section{Results and Discussion}

\section{a) Seedling emergence and pre-emergence mortality}

Every year, the seedling emergence of tomato was significantly increased over control due to treatment of $F$. oxysporum inoculated seedbed soil with $T$ harzianum bio-fungicides. Among the treatments the seedling emergence varied from $65.67-75.00,75.67-78.33$ and $70.67-76.67 \%$ where the emergence under control was 50.67, 61.00 and $49.67 \%$ in first, second and third year, respectively. Seedling emergence under various treatments with the bio-fungicides was not significantly different (Table 1). 


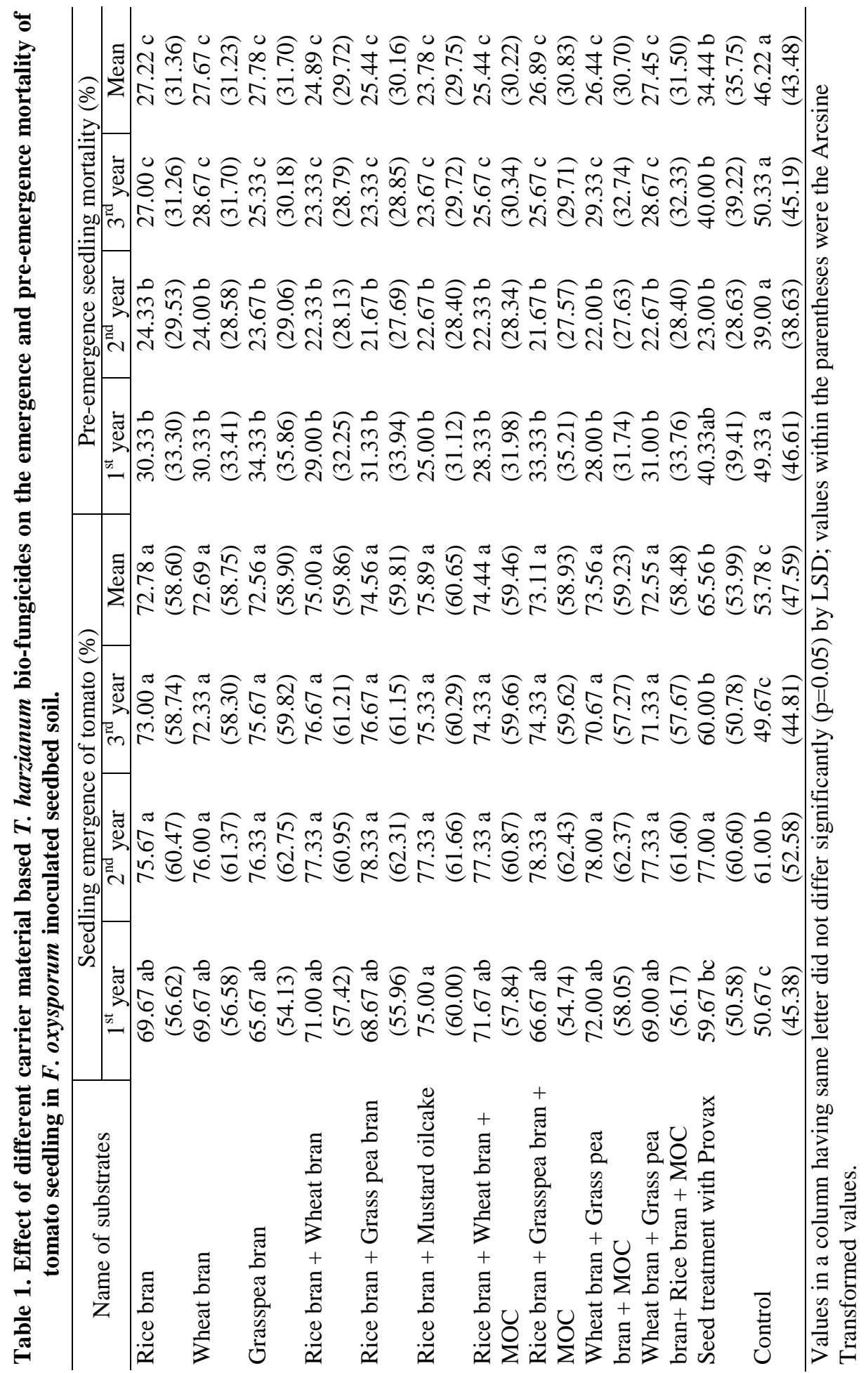


On the contrary, treatment of seedbed soils with the bio-fungicides caused significant reduction in pre-emergence seedling mortality of tomato compared to control. The range of seedling mortality was $25.00-34.33 \%$ in first year, 21.67$24.33 \%$ in second year and $23.33-29.33 \%$ in third year. The corresponding mortality under control was 49.33, 39.00 and 50.33\%, respectively. Efficacy of all treatments with the bio-fungicides to reduce the pre-emergence mortality was not significantly different (Table 1).

\section{b) Post-emergence mortality}

Post-emergence mortality of tomato in $F$. oxysporum inoculated seedbed soil was $23.67,31.67$ and $21.67 \%$ under control in $1^{\text {st }}, 2^{\text {nd }}$ and $3^{\text {rd }}$ year of study, respectively. Treatment of seedbed soil with the bio-fungicides reduced the disease incidence to $60.58-74.65,58.95-67.38$ and $64.61-67.70 \%$, respectively. The reduction was significant under every bio-fungicide. Efficacy of all treatments with the bio-fungicides to reduce the disease incidence was not significantly different (Table 2).

\section{c) Shoot growth}

Under control, shoot length was $23.53 \mathrm{~cm}$ in first year, $14.87 \mathrm{~cm}$ in second year and $16.13 \mathrm{~cm}$ in third year. Treatment of seedbed soils with $T$ harzianum based bio- fungicides multiplied on rice bran, wheat bran, grasspea bran alone or in different combinations increased the shoot length to 27.07-30.13, 15.87-19.33 and $24.17-33.60 \mathrm{~cm}$ in $1^{\text {st }}, 2^{\text {nd }}$ and $3^{\text {rd }}$ year, respectively. The shoot weight under control was 4.66, 4.10 and 4.23 gplant $^{-1}$ in first, second and third year, respectively. $T$. harzianum based bio-fungicidal treatments of seedbed soils increased the parameter to 7.34- 8.01, 5.51-6.71 and 6.97-10.03 gplant $^{-1}$, respectively. Every year, the increase in length and weight of shoot of tomato seedling due to biofungicidal seedbed soil treatment was significant compared to control. Effect of the treatments on shoot growth was more or less similar (Table 3).

\section{d) Root growth}

Every year, the root length of tomato seedling was significantly lower in nontreated seedbed (control) compared to bio-fungicide and Provax treated beds. In first, second and third year, the root length of tomato seedlings ranged 7.1310.17, 6.93- 8.27 and 6.87-10.67 $\mathrm{cm}$ under different treatments and 5.50, 4.70 and $4.97 \mathrm{~cm}$ in control seedbeds, respectively (Table 4).

In first, second and third year, the ranges of root weight were $0.42-0.46,0.50$ 0.58 and 0.71-0.95 gplant ${ }^{-1}$, respectively in seedbed treated with bio-fungicides multiplied on various substrate materials and $0.33,0.39$ and 0.54 gplant $^{-1}$ in control seedbeds, respectively (Table 4). The root weight was significantly higher compared to seedbeds received no bio-fungicide or Provax. Effect of the treatments on root growth was more or less similar (Table 4). 


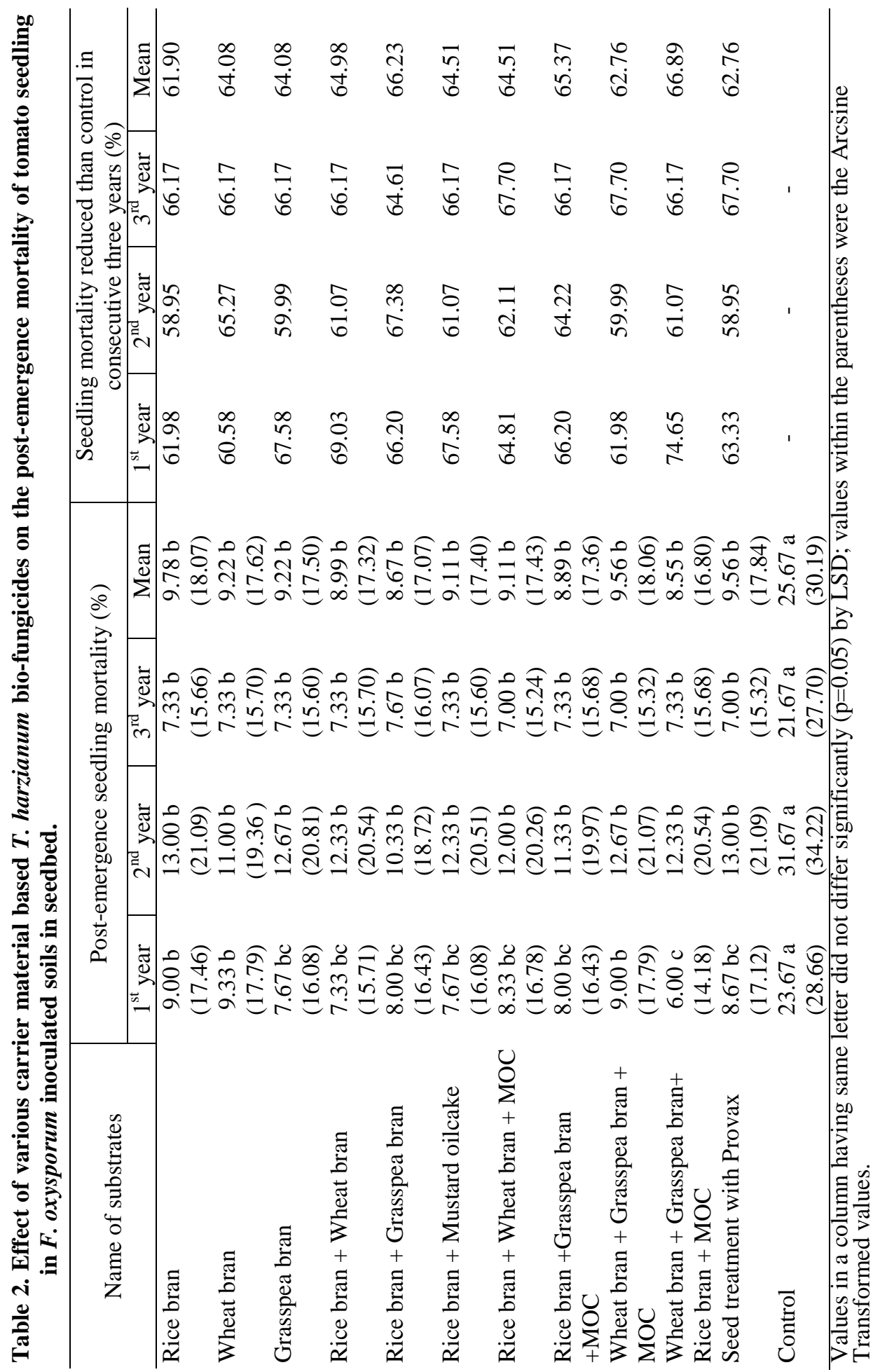




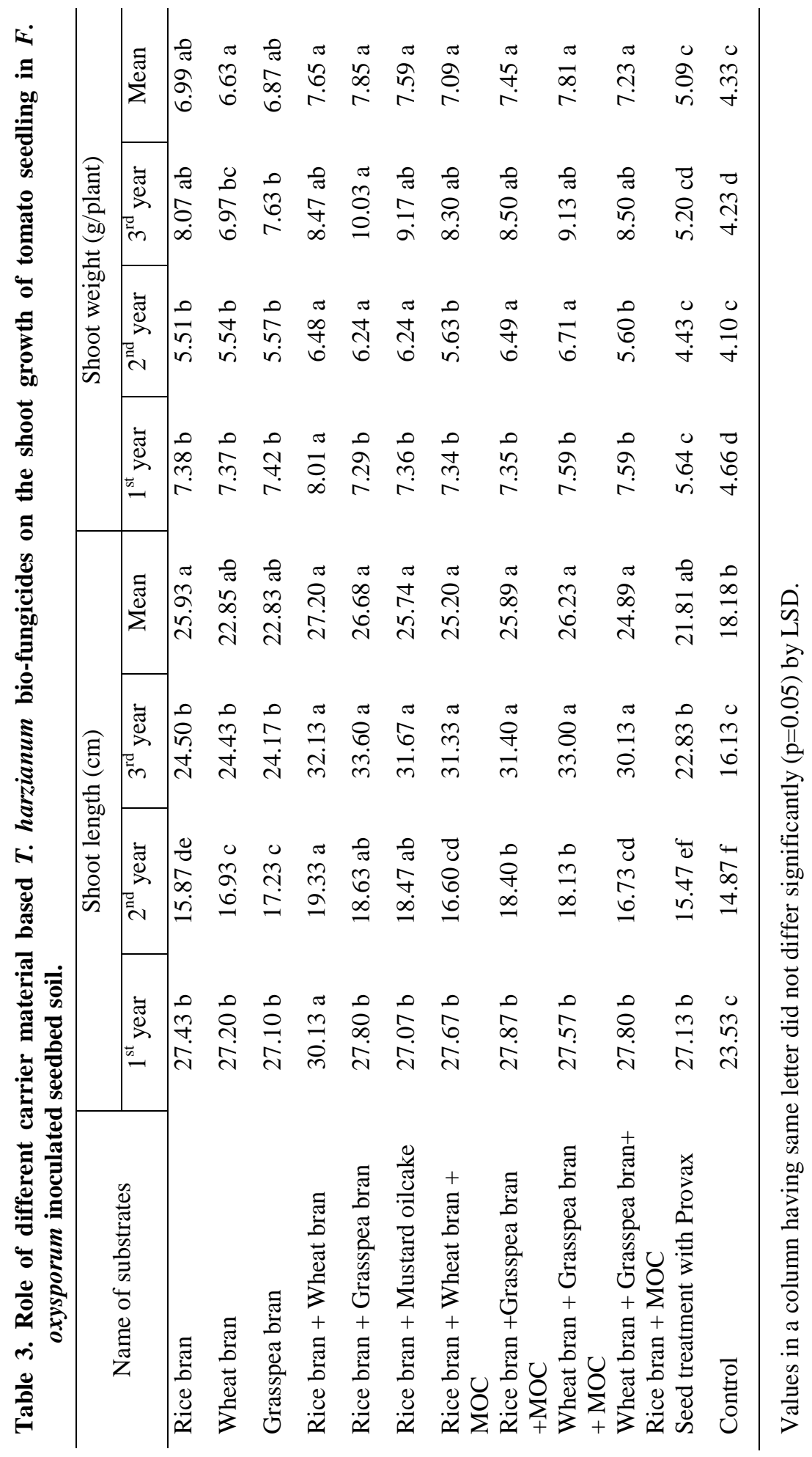




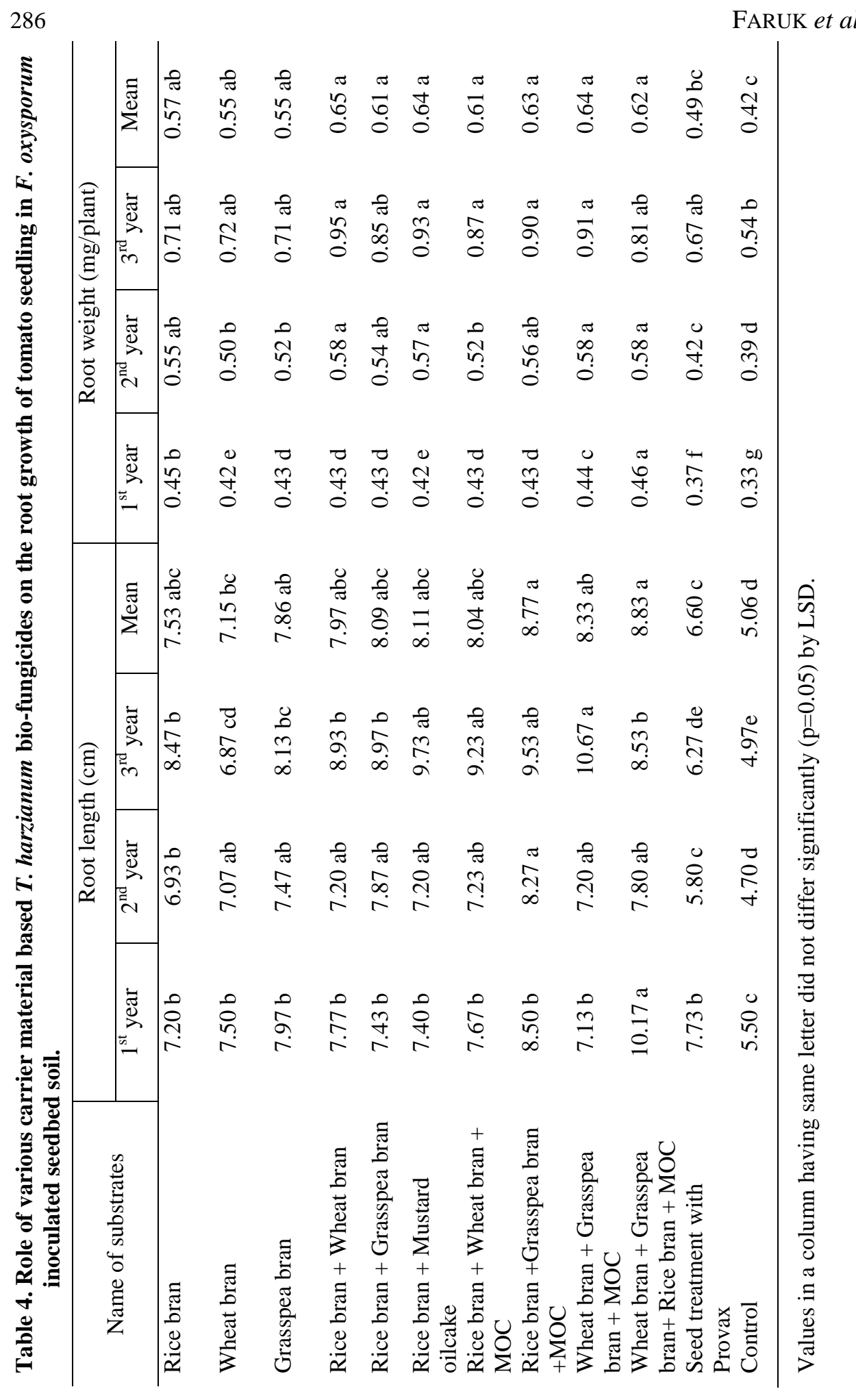




\section{e) Effect of Provax}

Treatment of seedbed soil infested with $F$ oxysporum with Provax also reduced the incidence of foot and root rot and increased shoot and root growth of tomato seedlings over control. However, its efficacy was lower compared to biofungicides (Tables 1-4).

Results of the present experiment reveal that efficacy of all $T$ harzianum based bio- fungicides multiplied on rice bran, wheat bran, grasspea bran used alone or in different combinations mixed with or without MOC are effective to control foot and root disease of tomato seedling in seedbed and to achieve satisfactory increase in seed germination, pre- and post-emergence seedling mortality. Similar findings have been reported by other researchers (Bentez et al., 2004; Mausam et al., 2007; Pros ad and Anes, 2008; John et al., 2010). The fungus Trichoderma harzianum, a well-known antagonistic fungus prevailing in the soil, was being used in many crops, like lettuce, tomato, onion, cotton, grapes, peas, apples, sweet corn and carrots to control various diseases caused by Phytophthora, Pythium, Sclerotinia, Botrytis, Rhizoctonia and Fusarium (Benítez et al., 2004; Mausam et al., 2007). It was reported that $T$. harzianum remarkably proliferated the root system and accelerated biological nitrogen fixation in addition to the reduction of diseases caused by $F$. oxysporum and Pythium spp. in legume crops (John et al., 2010). This findings are in accordance with the observation of the present study where soil is treated with different carrier material based $T$. harzianum bio-fungicides that enhanced the growth of tomato seedling in $F$. oxysporum inoculated seedbed soils though the degree of shoot and root growth varied among the treatments. Harman, (2006) and Manju and Mall, (2008) also reported positive role of Trichoderma species in increasing plant growth and productivity. In present experiment there is significant increase in emergence, shoot and root length and also shoot and root weights of tomato seedling due to T. harzianum bio-fungicides which is supported by the findings of many investigators (Prasad and Anes, 2008; Mishra and Sinha, 2000; ChaurTsuen and Chien-Yih, 2002). Enhanced seed germination due to Trichoderma species has also been reported by Mukhtar (2008). It has been reported that Trichoderma isolates possesses the ability to compete for key exudates from seeds that stimulate germination of propagules of plant pathogenic fungi in the soil as they compete with microorganisms for nutrient and space. The three well known mechanisms associated with pathogen control by Trichoderma were competition for nutrients, antibiosis, and myco-parasitism (Chet, 1987). It has been noticed by Tjamos et al. (1992) that $T$. harzianum controls $F$. oxysporum by competing for both rhizosphere colonization and nutrients. They observe that bio-control of targeted pathogen became more effective with the decline of nutrient concentration of the soil. The study confirm the reports of other researchers regarding the role of $T$. harzianum to enhance seed germination and 
root and shoot growth of seedlings (Dubey et al., 2007) as well as increasing the frequency of healthy plants (Rojo et al., 2007).

Rice bran based Trichoderma bio-fungicide gave maximum seed germination, reduced seedling mortality and increased growth of tomato seedling. Similar observation with wheat and rice bran for the formulation of $T$ harzianum biofungicide was reported by Sangeetha et at. (1993). Disease incidence of tomato, water melon and cotton was reported to be reduced considerably by the application of $T$ harzianum (Sivan and Chet, 1986). Shoresh et al. (2005) stated that Trichoderma spp. were effective bio-control agents for a number of soil borne plant pathogens and induced a potentate state in the plant enabling it to be more resistant to subsequent pathogen infection.

\section{Acknowledgement}

The authors thankfully acknowledged BAS-USDA who provided financial support and Bangladesh Agricultural Research Institute, Gazipur for extending necessary logistic support for smooth running of this research. Special thanks to Dr. T. K. Dey, former Chief Scientific Officer Plant Pathology Division, BARI for his fruitful counsel and directives. Thanks also go to the Scientific Assistant Mr. Md. Abdur Razzak and Mr. Zamil Akter for their sincere assistance in this research work.

\section{References}

Anonymous. 1992. Bangladesh Agricultural Research Institute (BARI) Annual Report (1991-92), BARI, 74p.

Anonymous. 2012. Year book of Agricultural Statistic of Bangladesh, Dhaka 149p.

Benítez, T., A. M. Rincón, M. C. Limón and A. C. Codón. 2004. Biocontrol mechanisms of Trichoderma strains. Int. Microbiol. 7:249-260.

Chaur-Tsuen, L. and L. Chien-Yih. 2002. Screening strains of Trichoderma spp. for plant growth enhancement in Taiwan. Plant Pathology Bulletin 11:215-220

Chet, I. 1987. Trichoderma -application, mode of action and potential as a biocontrol agent of soil borne plant pathogenic fungi. In: Chet I (ed.), Innovative approaches to plant disease control. Wiley, New York, Pp 137-160.

Das, B. C., S. K. Roy and L. C. Bora. 1997. Mass multiplication of Trichoderma species on different media. J. Agril. Sci. Society of North East India 10(1): 95-100.

Dubey, S. C., M. Suresha and B. Singha. 2007. Evaluation of Trichoderma species against Fusarium oxysporum f. sp. ciceris for integrated management of chickpea wilt. Biological Control 40: 118-127.

Harman, G. E. 2006. Overview of mechanisms and uses of Trichoderma spp. Phytopathology 96:190-194. 
John, R. P., R. D. Tyagi, D. Prévost, S. K. Brar, S. Pouleur and R. Y. Surampalli. 2010. Mycoparasitic Trichoderma viride as a biocontrol agent against Fusarium oxysporum f. sp. adzuki and Pythium arrhenomanes and as a growth promoter of soybean. Crop Protection 29(12): 1452-1459.

Manju, S. and T. P. Mall. 2008. Efficacy of Trichoderma species on Phytopthora dresceleri f.sp. cajani of Pigeon pea. Ann. Plant Prot. Sci. 16: 162-164.

Mausam V., K. B. Satinder, R.D. Tyagi, R.Y. Surampalli and J. R. Valero. 2007. Antagonistic fungi, Trichoderma spp.: Panoply of biological control. Biochemical Engineering J. 37: 1-20.

Mishra, D.S. and A.P. Sinha. 2000. Plant growth promoting activity of some fungal and bacteria agents on rice seed germination and seedling growth. Tropical Agric. 77:188-191.

Mukhtar, I. 2008. Influence of Trichoderma species on seed germination in okra. Mycopath. 6(1\&2): 47-50.

Prasad, D. and K. M. Anes. 2008. Effect of metabolites of Trichoderma harzianum and T. viride on plant growth and Meloidogyne incognita on okra. Ann. Plant Prot. Sci. 16: 461-465.

Rettinassabababy, C. and N. Ramadoss. 2000. Effect of different substrates on the growth and sporulation of Trichoderma viride native isolates. Agril. Sci. Digest. 20(3): 150-152.

Rojoa, F. G., M. M. Reynosoa, M. Fereza, S.N. Chulze and A. M. Torres. 2007. Biological control by Trichoderma species of Fusarium solani causing peanut brown root rot under field conditions. Crop Prot. 26:549-555.

Sangeetha, P., R. Jeyarajan, and S. Panicher. 1993. Mass multiplication of bio-control agent Trichoderma spp. Indian J. Mycol. Plant Pathol. 23(3): 328-330.

Shamsuzzaman, S. M. A. Islam and I. Hossain. 2003. Trichoderma culture and germination of sweet gourd seed. Bangladesh J. Seed Sci. and Tech. 7(1 and 2): 91-95.

Shoresh, M., I. Yedidia and I. Chet. 2005. Involvement of Jasmonic Acid/Ethylene Signaling Pathway in the Systemic Resistance Induced in Cucumber by Trichoderma asperellum $\mathrm{T}_{203}$. Phytopathology 95(1): 76-84.

Sivan, A. and I. Chet. 1986. Biological control of Fusarium spp. in cotton, wheat and muskmelon by Trichoderma harzianum. J. Phytopathol. 116(1):39-47.

Tjamos, E. C., G. C. Papavizas and R. J. Cook (eds) (1992) Biological control of plant diseases. Progress and challenges for the future. Plenum Press, New York. 